\title{
Preservation of The Begawi Abung Siwo Migo Tradition Development Oriented and Social Welfare in Lampung Multicultural Community
}

\author{
Ghozali Timbasz ${ }^{1}$, Syaripudin Basyar ${ }^{2}$, Fitri Yanti ${ }^{3}$, Hasan Basri ${ }^{4}$ \\ \{ghozalitimbasz@gmail.com ${ }^{\text {, syaripbasar@gmail.com² }}$, fitriyanti@radenintan.ac.id ${ }^{3}$, \\ gadila.lpg12345@gmail.com ${ }^{4}$ \}
}

Raden Intan State Islamic University of Lampung, Bandar Lampung, Indonesia ${ }^{1}$, Raden Intan State Islamic University of Lampung, Bandar Lampung, Indonesia ${ }^{2}$, Raden Intan State Islamic University of Lampung, Bandar Lampung, Indonesia ${ }^{3}$, Tulang Bawang University, Bandar Lampung, Indonesia ${ }^{4}$

\begin{abstract}
The Begawi tradition is the Pepadun Lampung culture and part of the national culture. The preservation of traditions that are oriented towards development and community welfare is a complex issue when faced with the progress of the times and diversity, so that efforts are needed to respect, maintain and preserve it. Therefore, this research is expected to provide positive output. This research focuses on the preservation of the Begawi tradition, as the highest ritual in the Lampung Pepadun traditional ceremony, Sub Fokus Abung Siwo Migo. This research is a field research. Based on the research results, tradition can contribute to the welfare of society if there are efforts to develop identity, including respect for traditional cultural values and values of social solidarity. To achieve the objectives in this study, changes are needed that lead to the development of the character of society to include harmony in individual aspects and human sociality, meaning that tradition is carried out because of tradition, for the sake of tradition. and the existence of a tradition that underlies the identity of the Lampung people, so that the tradition can be lived with a sense of comfort and safety by its owner. In addition, the community is expected to be able to identify the values and ideals of the tradition itself, as the heir of responsibility, both individuals, the wider community and local governments, in carrying out the mandate of the law.
\end{abstract}

Keywords: Begawi ASM Tradition, Development Oriented, and Social Welfare

\section{Introduction}

Culture as a result of the development of a nation is critical to learn in order to know and maintain various aspects of diversity that exist in pluralistic Indonesian society, both in terms of ethnicity, social, culture, politics, and religion, so that people can always live in harmony amidst the diversity of cultures and systems. Kinship as the identity of the nation and the State.

The concept of cultural diversity, which is multiculturalism, is also regulated in the 1945 Law, Article 32 paragraph (1) and paragraph (2), concerning the State's obligation to promote national culture and Article 18 B paragraph (2) concerning Regional Government. These laws and regulations place national culture at a high degree and guarantee the elements of regional culture and emphasize the nation's diversity by the principle of Bhinneka Tunggal Ika. 
The preservation of diversity, plurality, plurality, or multiculturalism in a community is lovely and can provide positive energy and can be used as capital to live together to build a nation in a give and take relationship. However, it requires cultural resilience to reduce the forces that arise as a result of diversity. As explained by Masdar Helmi [1], if diversity is seen as different and is still framed by an interpretation that comes from a symbol that suppresses prejudice, suspicion, bias, and reduction against groups outside of itself, it can lead to cultural domination, which in turn creating a cultural clash, this will only be a bomb that destroys the structure and pillars of the nationality.Lampung people are an indigenous ethnicity who has built a system of social life with unique traditions, unique languages, and uniqueness of writing for centuries. The uniqueness of tradition is that the people of Lampung have a muaghi tradition, a ninjuk or sebambangan tradition in a marriage, a begawi tradition, and so on. While the language tradition, the people of Lampung have two dialects, namely the dialect of "Api" (A), which is identical to the people of the margins, and the dialect of "Nyo" (O), which is identified with the Abung people. In terms of tradition, the people of Lampung consist of two major groups: the Jurai Pepadun, which is followed by the Abung people, and the Jurai Sebatin, followed by the People who are marginalized or coastal.

In one element of cultural activities (culture traits), large ceremonies that have become the society's traditional culture in several regions in Indonesia are often found or found differences in technicalities and procedures for their implementation. Like the Begawi Puppung Pepadun tradition, which applies to the Lampung Pepadun people. The Begawi traditional ceremony aims to increase one's social strata to be more respectable in a position of customs or balance and take the title Suttan or Suntan or the like. The title Suttan can be interpreted as the title of a person given by local traditional leaders after fulfilling specific requirements, namely by slaughtering several buffaloes/cows and various other ritual activities carried out during the ceremony. The implementation of begawi involves clan and customary community leaders, is costly, and takes three to seven days. Almost the same meaning as the Batagak Pengulu ceremony tradition in the Minangkabau ethnic community (West Sumatra). When a tribe or clan appoints a new leader of its people, the Batagak Pangulu ceremony is held. This ceremony is a meaningful ceremony by slaughtering a buffalo and holding a party for three days or even a week. Many other traditional traditions exist in Indonesia as a form of diversity and plurality, multiculturalism, and cultural pluralism, all of which is the grace of Allah SWT.

Seeing the importance of the socio-cultural life system as a legacy of the past and becoming a nation's identity, traditional socio-cultural values must be respected, preserved, and preserved. They are well preserved and not eroded by the times. Because of the weak understanding and knowledge of the meaning and reduction of traditional values, it tends to make people prefer and adopt foreign cultural practices rather than preserving their own regional culture. Therefore, a traditional culture which is taught from generation to generation, there is no guarantee that it will remain strong in facing globalization, which offers a pragmatic and consumptive lifestyle, including the ability of local communities to identify potential cultural wisdom, both in the form of natural resources, social capital, and values. Moreover, local institutions or other sources are owned.

Traditional culture is considered an ancient, worthless scene, expensive, convoluted and tedious, the incomprehensible language of the embodiment, and so on, is a point of view that cornered to identify weaknesses in preserving traditional culture. Lampung's cultural philosophy, which is always echoed, researched by many experts, cannot always change modern society's principles to prioritize tradition over modern culture. This is a challenge to describe a series of science as well as about the meaning and main ideas contained in the 
Lampung Pepadun customs, especially the begawi tradition, as an implementation of the development of a cultured and religious society, as well as finding solutions to develop traditional Lampung culture with national and international expectations to achieve prosperity. Social for the community.

The ethical and moral values contained in the tradition of a society are the main social assets or capital in order to empower the community in order to improve the quality of life and welfare, at the same time eliminating access to modernization, which can destroy the bonds of traditional values such as kinship, cooperation. Religious values, local customs, and cultural institutions are entrenched and rooted in social life formation, thus forming national cultural values.

Arif Budimanta et al. [2] explain that cultural development is an effort to improve or maintain society's traditions in community development studies that describe how cultural and community changes occur from time to time due to globalization. In general, community development (community development) is a development activity carried out systematically, planned, and directed to increase public access to achieve better social, economical, and quality of life conditions compared to previous development activities.

Cultural development must be based on noble values based on Pancasila so that it always animates every aspect of development. It needs to be directed to revitalize local values, norms, traditions, and wisdom in responding to various acute problems of the nation such as corruption, poverty, and social inequality through government support and exemplary community organizations in elevating the noble traditional regional cultural values, as well as filtering and absorbing positive external cultural values towards the advancement of civilization and enhancing the degree of humanity in line with changing times as well as beneficial interests for the improvement of progress, welfare, and community independence. Thus the goal of developing traditional culture can be achieved. The potential richness of local wisdom can be found as an identity of an inseparable area from national culture.

Etymologically according to Nanih Machendrawati [3]. Development means empowering, strengthening, fostering, and prospering. In terms of terminology, the development of an Islamic community means a concerted and planned effort to prosper Muslims in all aspects of their lives according to the Koran and Sunnah's demands, whereas lexically, empowerment means strengthening. Technically, the term empowerment can be equated or at least equated with the term development; even these two terms, to some extent, are interchangeable or interchangeable.

To realize community development systematically, planned manner to achieve better social, economic, and quality conditions of life. According to Jim Ife, [4], cultural heritage must not be separated but must be seen as a real part of people's lives. If this is done, tradition can become a central point for social interaction and an essential process in community development such as social, economic, and political development. This means that the developer requires community participation as a form of social action that can be assumed as a pattern of community action that responds to what is happening around them. The response, in this case, is aimed at making use of local wisdom as a means of supporting the development of traditional culture in order to improve social welfare.

Development-oriented traditional culture and social welfare is a complex problem that must be faced when faced with the progress of the times in the current era of globalization. National culture, which is expected to be able to act as a catalyst in adopting universal values as well as a filter against the entry of negative global cultures, has not been able to function correctly, resulting in a symptom of an identity crisis as a result of the weakening of cultural norms that have not been adequately consolidated. This results in ambivalence and 
disorientation in values. The disorientation of values impacts the development of a spirit of freedom that creates a permissive viewpoint. If this develops excessively, it will make it difficult for efforts to integrate development measures and trigger conflicts in various levels of life.

Therefore, an urgent problem in the development of traditional culture is the tendency to decrease the level of management of local cultural assets, both tangible and intangible, especially traditions that exist after regional autonomy. This will be dangerous for preserving local culture and even national culture, which plays a vital role in maintaining historical ties and is also very important as a source of knowledge.

This research is focused on the study of the preservation of the Abung Siwo Migo begawi tradition. This study's sub-focus is Begawi Puppung Pepadun, where this activity is the highest or peak ritual in a Lampung Pepadun ritual to improve the social balance strata on the position of customs and the development of traditional culture in order to achieve social welfare for the community.

Based on the background of the problem as described above, problems can be formulated regarding; What is the accommodation of the Abung Siwo Migo begawi tradition for the social welfare of the community and how are the strategic initiative of the Regional Government and stakeholders in developing the Abung Siwo Migo begawi tradition in the Multicultural Lampung community. The goals to be achieved are:

a. The traditional culture of begawi is preserved in the Abung Siwo Migo community of Lampung province as mandated by the Constitution.

b. Developing national and international cultural begawi

c. Encouraging government and stakeholder policies to initiate the preservation of traditional culture, oriented to the development of social welfare

\section{Literature Review}

\subsection{Begawi Tradition Accommodation for Social Welfare}

The term accommodation always appears in various science fields with different meanings, such as accommodation in education, health, communication science, psychology, and others. The point is that accommodation aims as an adjustment so that problems, conflicts do not occur. , conflict, and creates comfort.In the Big Indonesian Dictionary, viewed from a sociological perspective, accommodation means a social adjustment in humans' personal and group interactions even though there are differences. In other understanding, Richard West [5] defines accommodation as the ability to adjust, modify, or regulate one's behavior in response to others.

According to Gillin and Gillin in Soerjono Soekanto [6], accommodation is a social relationship process that leads to adaptation. Between individuals or groups, there is an adaptive relationship to overcome tensions. These social adjustments can take the form of coercion, compromise, arbitration involving other parties, conciliation, tolerance, stalemate, adjudication, or legal settlement. However, understanding in the context of social accommodation of the tradition in question is more towards tolerance of thought, which can agree on the meaning and main ideas of a custom or custom in a community organization, especially the begawi tradition realize cooperation between living social groups. Collectively but have different perspectives on culture and religion, and unite these social groups to increase social welfare by developing their traditional culture. 
Tradition is the habit of society in interacting with the environment and the universe. The values contained therein have been arranged in such a way from time to time, and are used as a means of non-formal education regarding the values of life for the generation to generation. This means that indirectly, tradition has taught the relationship between people, safeguarding human dignity, and others. In essence, we are required to take responsibility for its preservation so that tradition will always exist in the life of society, nation, and State.

In the sociology dictionary, tradition is defined as a hereditary belief that can be maintained. Meanwhile, according to Piotr Sztompka [7], another definition of tradition is all material objects and ideas that come from the past but still exist today, have not been destroyed, destroyed, or forgotten. Here tradition only means inheritance; what is left from the past.

Likewise, Muhammad Abed al-Jabiri [8] explained that the meaning of tradition in Arabic is understood by the word turat, which comes from the letters $g$, (wa), $\lrcorner$ (ra), and $ت$ (tha), which in the classical dictionary emphasizes with the words irth, wirth, and mirath. Everything is a form of masdar (verbal noun) that shows the meaning of everything humans inherit from their parents, either in the form of property or rank or dignity.

Specifically, by C.A. Van Reusen [9]. Tradition is translated as inheritance or customary norms, rules, assets. However, tradition is not something that cannot be changed, uplifted, and rejected; on the contrary, it can be combined with various human actions and raised on the whole. Furthermore, the understanding, according to Bastomi Suwaji [10], that tradition is the spirit of a culture, with the cultural system, the tradition will become strong. If tradition is eliminating, the hope of culture will end right away. Everything becomes a tradition, its effectiveness, and level of efficiency have been tested. Its effectiveness and efficiency always follow the development of cultural elements. Various forms of attitudes and actions in overcoming problems if the level of effectiveness and efficiency are low will soon be abandoned by the perpetrators and will not become a tradition. Of course, a tradition will fit and fit the situation and conditions of the people who inherit it. Based on this understanding, it can be summarized that tradition is a legacy of the past as a form of richness in the history and spirit of a culture so that tradition can create a harmonious life in various communities of society if it is lived with mutual respect, respect, by existing values and rules.

Abung Siwo Migo is one of Lampung's indigenous people with the Pepadun culture, which became the forerunner to the formation of Central Lampung Regency. Siwo Migo said because he has nine clans or brothers or kinship that are scattering several areas in Lampung Province. The nine elements of culture: Buay Niliki, Buay Unyi, Buay Subing, Buay Nuban, Buay Beliuk, Buay Nyerupo, and Buay Selagai, Buay Kunang, and Buay Anak Tuho.

There are five customary unitary sub-communities within the Pepadun customary Lampung community, namely Abung Siwo Migo, Megow Pak Tulang Bawang, Way Kanan Limo Kebuayan, Pubian Telu Suku, and Sungkai Bunga Mayang. The five customary subcommunities are scattering in various regencies/cities in Lampung Province, such as Central Lampung Regency, North Lampung Regency, East Lampung Regency, Way Kanan Regency, Tulang Bawang Regency, Tulang Bawang Barat Regency, and Bandar Lampung City, including a small number of Regencies. South Lampung.

The Pepadun customary unit's sub-community above is included in the form of a stratified (genealogical) customary community tied to the same lineage from one ancestor. Each group has similarities in terms of custom elements, both the marriage system and the Begawi traditional ceremony, all of which have been regulated in the decisions of traditional balancing figures in each region. 
In the implementation of the begawi tradition, it is motivated by several reasons, namely because of the cause of marriage, and because of deliberate reasons to carry out begawi to improve one's social status. The series of begawi traditions, especially in the Abung Siwo Migo community, have various interpretations of benefits and Islamic principles, including aspects of social welfare. Therefore, this fact inspires researchers to examine matters related to customs, especially regarding the accommodation of Abung Siwo Migo's traditional begawi traditions for the social welfare of the people in Lampung Province, so that it expected to provide positive output to strengthen the function and role of traditional institutions in revitalizing the development of traditional cultural values, especially the Begawi Puppung Pepadun tradition as a form of community development participation.

\subsection{The Development of Begawi Traditions Towards Social Welfare}

Cultural wellbeing is an essential concept in cultural development and community development, which is always interesting to research. So far, there have been many discussion perspectives on cultural welfare that have become the focus of scientists, academics, and socio-cultural observers in Indonesia. However, studies of the traditional begawi cultural welfare that exist in the pepedun community in Lampung Province have not been widely developed, even though the begawi tradition in Lampung pepadun custom is a tradition that includes all the elements of existing traditional rituals, both rituals in marriage, rituals in the seangkenan / muaghi customs, dance traditions, kulintang art, tadisi bujang Gadis (ngedio), and others, where all these elements are summarized inside it. Therefore, through a qualitative approach that will be used in this study, related to aspects of cultural wellbeing on the case study of the Begawi Abung Siwo Migo tradition, it is hoped that it can have a positive impact in minimizing cultural shifts and identity crises so that the development of the begawi tradition can develop in terms of regulations. Broader in the context of realizing the social welfare of the community.

In-Law No. 11 of 2019, regarding social welfare. Article 1 explains that social welfare is a condition for the fulfillment of the material, spiritual and social needs of citizens in order to live correctly and be able to develop themselves so that they can carry out their social functions.

Albert and Hahnel, as quoted by Eddy Sugiarto [11], divide welfare theory into three parts, namely; Classical utilitarian, Neoclassical welfare theory, and New contraction approach. The classical utilitarian approach emphasizes that one's pleasure or satisfaction can be measured. The principle for individuals is to increase the level of their welfare as much as possible. As for the community, increasing their group's welfare is a principle that is upheld in their life. The neoclassical welfare theory approach is a function of all individual satisfaction. The new contraction approach is to raise the maximum freedom in an individual's life or a person. This approach emphasizes that individuals will maximize their freedom to pursue goods and services without interference from certain parties.

Based on the description above, to realize social welfare through the concept of traditional cultural development, of course, it cannot be separated from our understanding of traditional knowledge or better known as local knowledge or indigenous knowledge, whose meaning is to focus on knowledge that already exists in a community. The term traditional knowledge, M. Marwan and Jimmy [12] in the national law dictionary, means that traditional knowledge possessed by local communities or traditions that are hereditary includes the fields of art, plants, architecture, etc. Further defined by Henry Soelistyo, quoted by Muhammad Djumhana [13], traditional knowledge is knowledge whose status and use are part of society's cultural tradition. Understanding traditional knowledge can 
also be seen in full in the article J. Traditional Knowledge, Innovations, and International Practices, in Agus Riswandi, et al. [14];

"Traditional knowledge refers to the knowledge, innovations, and practices of indigenous and local communities worldwide. Developed from experience gained over the centuries and adapted to the local culture and environment, traditional knowledge is transmitted orally from generation to generation. It tends to be collectively owned and forms stories, songs, folklore, proverbs, cultural values, beliefs, rituals, community laws, the local language, and agricultural practices, including plant species and animal breeds. Traditional knowledge is mainly practical, particularly in such fields as agriculture, fisheries, health, horticultural, and forestry."

Traditional knowledge refers to knowledge, innovations, and practices from indigenous and local communities around the world. Developed from experiences through countries and adapted to local cultures and environments, traditional knowledge is transmitted orally from generation to generation. It becomes collective ownership of the form of stories, songs, proverbs, cultural values, beliefs, rituals, community law, regional languages, and agricultural practices, including plant species and animal descent. Traditional knowledge is primarily a natural practice in agriculture, health, horticulture, and forestry.

Furthermore, in another sense, Afifah Kusumadara [15] argues that traditional knowledge is seen as intellectual work in the field of knowledge and technology, which contains elements of traditional inheritance characteristics that are produced, developed, and maintained by local communities or indigenous peoples in an area.

From some of the above definitions, it can help the author to explain the formulation of concepts and operational definitions of this scientific research, making it easier to understand problems, apply theory and research methodology consistently in their implementation in the field. Therefore, by referring to several theories correctly, logically, and systematically, it will be built on the grand theory, middle theory, and applied theory. The three complement and reinforce one another.

\section{Research Methodology}

This type of research is classified as field research (field research), namely research that uses information from the research objectives through observation, interviews, and documentation. The method used is a qualitative approach to finding and collecting various primary data sources (primary) and supporting data sources (secondary). The three mechanisms used in data collection in this study tend to use the Miles and Hubermen model, described in the form of data analysis components. Furthermore, checking the validity of the data was carried out using four criteria: credibility, transferability, dependability, and confirmability.

\section{Results and Discussion}

Analysis of social change will touch on the concepts of traditional culture, accommodation, and modernization. These three concepts are inseparable because they give life to all the elements. Tradition is a mechanization tool to adapt to the progress of the times. 
When the modernization tradition goes hand in hand, accommodation becomes part of the social process dynamics to anticipate problems that will arise later.

The essential thing about the Abung Siwo Migo begawi tradition accommodation is the information passed on from generation to generation, both oral and written, because, without this, traditional culture cannot contribute to society can even lead to extinction. Thus tradition is born in 2 (two) ways, namely:

a. It is emerging from below through a mechanism of spontaneous emergence involving the public at large. For some reason, specific individuals find historical legacies that attract attention, unusualness, love, and admiration, spread in various ways, influencing society. This respectful attitude turns into behavior in the form of ceremonies, research and restoration of ancestral relics, and reinterpreting old beliefs.

b. Appears from above through a mechanism that must be habituated or forced. This means that something that is considered a tradition is chosen and made public attention by an influential or powerful individual; in this case, it is the Government.

An analysis of social change should not make the difference between tradition and modernization. The terms traditional and modern society are just mental constructions that form simplified models to understand and explain the complexities of history, as Shil [16] in Piotr Sztompka's book [17] asserts that: "Humans cannot live without tradition. although they often feel dissatisfied with their traditions."

\section{Conclusion}

Based on the results of this study it can be concluded that; In general, the begawi tradition as traditional socio-cultural values is still very relevant and lives on in the midst of the multicultural society of Lampung. Considering that traditional values have a role in the relationship to the Abung Siwo Migo indigenous people, the begawi tradition is used as a sacred activity which is a representative or embodiment of the ideology or philosophy of the people of Lampung, namely Piil-pusanggiri (ashamed of doing despicable work according to religion and having self-respect); Juluk-adok (having a personality in accordance with the customary title it bears); Meet-nyimah (visit each other for hospitality and welcoming guests); Nengah-mixed (active in social interactions and not individualistic); and Sakaisambaian (mutual cooperation and mutual assistance with other community members).

To achieve the objectives in this research; (first) there needs to be a change that leads to the development of the character of the community in order to contain the harmony of individual aspects and human sociality. Where the first principle in the development of tradition is co-existence. This means that the traditional culture (begawi) carried out by the indigenous people is based, because of the existence of tradition, for the existence of traditions, and for the sake of the existence of the traditions of the Lampung people. Coexistence is what underlies the identity of the people of Lampung, so that the tradition will be carried out with a sense of comfort and safety by the owner, besides that the community is expected to be able to recognize the values and ideals of the tradition itself, as an heir of responsibility, both individually, indigenous peoples or local governments, in order to carry out the mandate of the law. (second), it is necessary to have information transmitted from generation to generation, both oral and written, so that traditional culture does not become extinct, as well as an effort to develop traditional cultural wisdom. (third) motivate the development of tradition in two ways; (1). Emerging from the bottom (bottom up) through a 
mechanism spontaneously and involving the public at large, for a reason, certain individuals find historical heritage that attracts attention, unusualness, love and admiration which are then spread in various ways, influencing the public at large. This respectful attitude turns into behavior in the form of ceremonies, research and restoration of ancestral relics and reinterpreting old beliefs. (2). Appears from above (top dwon) through a mechanism that must be habituated or forced. This means that something that is considered a tradition is chosen and made public attention by an influential or powerful individual in this case is the Government.

\section{References}

[1]Afifah Kusumadara.: Maintenance and Preservation of Traditional Knowledge and Expressions of Indonesian Traditional Culture, pp. 22. Journal; Protection of Intellectual Property Rights and NonIntellectual Property Rights (2011)

[2]Agus Riswandi and M.: Syamsuddin. Intellectual Property Rights and Cultural Law, pp. 29. Jakarta: Rajawali Pers (2004)

[3]Albert and Hahnel.: Traditional Welfare Theory, See Eddy Sugiarto, Socio-Economic Welfare Theory, and Its Measurement, pp.263-269. Executive (2005)

[4]Journal: Volume IV, No II, (August 2007)Shils in Szompka, Sociology of Social Change, pp. 74. (Yogyakarta: Prenanda media group (2007)

[5]Arif Budimanta and Bambang Rudito.: Community Development Management Methods and Techniques, pp. 33. Jakarta: CSD (2008)

[6]Bastomi Suwaji.: Appreciation of Traditional Arts, pp. 14. Semarang: IKIP Semarang Press (1986)

[7] C.A. van Peursen.: Cultural Strategy, pp. 115. Yogyakarta: Kanisisus (1992)

[8]Jim Ife, Frank Tesoriero.: Community Development, Alternative Community Development in the Age of Globalization, pp.451. Yogyakarta, Student Library (2016)

[9]Gillin and Gillin.: Cultural Sociology, a Revision of An Introduction to Sociology. (New York: The Macmillan Company, 1954). See Soerjono Soekanto, Sociology of an Introduction. Jakarta: P.T. Raja Grafindo Persada (2007)

[10]Big Indonesian Dictionary, Center for Language Development and Development. Jakarta: Balai Pustaka, cet. 3 (1990)

[11]Masdar Hilmy.: Initiating a Multiculturalism-Based Education Paradigm. Ulummuna Journal; Volume VII, Issue 12 Number 2 pp. 333 (July-December 2003)

[12]Muhammad Abed al-Jabiri.: Islamic post-traditionalism, trans. Ahmad Baso. Yogyakarta: Lkis (2000)

[13]M. Marwan and Jimmy. P.: Legal Dictionary, pp. 613. Surabaya: Reality Publisher (2009)

[14]Muhammad Djumhan.: Development of Doctrine and Theory of Protection of Intellectual Property Rights, pp. 14. Bandung: Citra Adiya Bakti (2006)

[15]Nanih Machendrawati and Agus Ahmad Syafe' i.: Islamic Community Development, pp.27. Bandung: P.T. Rosdakarya (2001)

[16]Piotr Sztompka.: Sociology of Social Change, pp.60-70.Jakarta: Prenada Media Group(2011)

[17]Richard West and Lynn H. Turner.: Introduction to Communication Theory.pp.27. Jakarta: Salemba Humanika (2009]

[18]Soejono Soekanto.: Sociology Dictionary, pp.69. Jakarta: P.T. Raja Gravindo Persada (1993)

[19]Law (U.U.), Chapter I. General Provisions, Article 1, Concerning Social Welfare. L.N. 2009 / No.

12, TLN NO. 4967, LL SETNEG: 32 HLM, (16 January 2009) 